\title{
Technical Efficiency of Public Service Hospitals in Indonesia: A Data Envelopment Analysis (DEA)
}

\author{
Sonny Harry B. Harmadi ${ }^{1} \&$ Irwandy $^{2}$ \\ ${ }^{1}$ Faculty of Economics and Business, Universitas Indonesia, Indonesia \\ ${ }^{2}$ Universitas Hasanuddin, Indonesia \\ Correspondence: Dr. Sonny Harry B. Harmadi, Faculty of Economics and Business, Universitas Indonesia, \\ Depok, Jawa Barat, 16424, Indonesia. E-mail: sonnyhbh@gmail.com
}

Received: March 26, $2018 \quad$ Accepted: April 6, $2018 \quad$ Online Published: May 28, 2018

doi:10.5539/ass.v14n6p81 URL: https://doi.org/10.5539/ass.v14n6p81

\begin{abstract}
In order to promote efficiency and the development of hospitals' services, the Government of Indonesia has issued specific policy which require all of the government-owned hospitals to be managed based on the principals applied in public services agency (Badan Layanan Umum/Badan Layanan Umum Daerah (BLU/BLUD)). The policy of BLU/BLUD is to grant each hospital authorization in managing their funds and resources under the principles of public accounting. Unfortunately, not all government-owned hospitals were granted BLU/BLUD authorization, especially hospitals outside of Jakarta, because local government did not wish to lose one of their main income. The main focus of this research is to calculate the efficiency of the hospitals of which have been granted BLU/BLUD, since one of the main purposes of BLU/BLUD is to provide high quality and efficient health care to the public. The measurement of hospitals' efficiency is not an easy thing to do, since there are so many inputs and outputs that were related to each other. Which is why, this research is measuring the efficiency level using the DEA (Data Envelopment Analysis) which is able to provide efficiency calculation with multiple inputs and outputs. With the total samples of 82 BLU/BLUD hospitals, this research concluded that the average of hospital's efficiency score is still on the level of $78.9 \%$ out of $100 \%$.
\end{abstract}

Keywords: Data envelopment analysis (DEA), hospital efficiency, Indonesia, technical efficiency

\section{Introduction}

Hospitals as type of health care facilities have such strategic role in order to accelerate the public's health to reach the Indonesian Health Development Target. Unfortunately, such target will only be possible if Indonesia is able to provide high quality health care services. The service quality is one of many performance indicators for health care providers including hospitals. The main purpose of health care systems all around the world is to achieve the optimal efficiency. The importance of efficiency as one of the main indicators of hospital's performance measurement, has been acknowledged in all around the world by the insertion of efficiency indicators inside the Europe Path Project's Hospital Performance Measurement by WHO.

In Indonesia, health care efficiency has been the main issue in the health care system. This has been made by the entry of free market era and the establishment National Health Security Program (Program Jaminan Kesehatan Nasional/JKN) on January $1^{\text {st }} 2014$ to achieve universal health coverage in Indonesia. The applicaton of JKN has brought such a big change in health care system by changing the payment system from 'fee for service' into 'service package' payment by social security provided by the government under the program of BPJS (Badan Penyelenggara Jaminan Sosial/Social Insurance Administration Organization) Kesehatan. By using INA-CBGs tariffs, and other strict rules regarding tiered referral systems, BPJS Kesehatan provides all the health care services from primary health care services to referred health care services like hospitals. Referred health care services are health care services management which handle the transfers between duties and responsibility of health care services both horizontally and vertically to the member of health insurance or social health insurance and the whole health care facility.

Indonesian government realized how important it is to be efficient in every aspect, thus introduced the General Services Pattern (PK-BLU) for any health care provider institutions which rules are applied under Indonesian Government Regulation number 1 on year 2004 about The National's Treasury. Government also issued regulations number 44 on year 2009 about hospitals, which mandates government-owned hospitals to be 
managed under the form of General Services (BLU/Badan Layanan Umum) or Area General Services (BLUD/Badan Layanan Umum Daerah).

Transformation of Indonesian public sectors institutions in the year of 1990's to early 2000's occurred under some certain circumstances which are: (1) rightsizing (cut the government) by reorganizing organizations to cut bureaucracy in order to gain efficiency (2) corporatization (managing for results) by creating auotonomous agencies in the government institution to be working corporate wise, (3) privatization, which allowed public sectors to be acquired by private parties. Under the case of BLU, the transformation pattern applies are the same as the corporatization pattern. As an autonomous agent, BLU's characteristics are not the same as other institutions as described below:

Table 1. The comparison of public sector institutions in Indonesia

\begin{tabular}{cccc}
\hline Criteria & Ordinary Institutions & General Services (BLU) & State Owned Corporation \\
\hline Legal Status & Part of Ministry or & Part of Ministry or & Legal Entity / State Assets \\
& Institutions & Institutions & are separated \\
Purpose & Non profit & Not for profit & Profit \\
& & Autonomous & Corporation \\
Management & Ministry-wise & Nomenclature & Limited \\
& & Governmental & Business \\
\hline
\end{tabular}

BLUs are operating as the ministry/institution/area governments working units to provide services whose managements are authorized and delegated by their parent institutions. BLUs under the authorization of central government are called BLU, while the ones whose authorizations are under the area government are called BLUD. BLUs are formed to improve services to the public by being granted the flexibility of financial management under the principles of efficiency, effectively, productivity and also healthy business practice application. By the presence of flexibilities, BLUs are expected to be able to increase services and financial performance of hospitals, so that they will be able to provide optimal health care services in the competitive health care market.

Until now, the number of government-owned hospitals with the status of BLU/BLUD in Indonesia is keep on increasing. On 2014, 241 hospitals were granted BLU/BLUD status, while on 2016 the number raised to 353 hospitals with 74 BLU hospitals and the other 279 are BLUD. Although the number is keep on increasing, not all government-owned hospitals are BLU, especially area government hospitals. This is caused by the low commitment on some area government to grant autonomy on financial management to their hospitals, and hospitals are their one of the most crucial income.

Based on the resources, hospitals in Indonesia are divided into class A, B, C and D. Class A hospitals are able to provide specialists and subspecialists doctors and have been set as top referral hospitals or central hospitals. Class B hospitals are able to provide wide range of specialists but with restricted subspecialists. These types of hospitals are planned to be built in each of Indonesian capital city of the provinces which are able to provide referral from district's hospital. Class $\mathrm{C}$ hospitals are able to provide restricted subspecialist doctors.

There are four types of specialized services which are internists, surgery, child health services and obstetrics. These types of hospitals are built in the cities or districts as level 2 health facilities which can accommodate referrals from level 1 health care facilities. Class D hospitals are transitional, because these hospitals will be improved into Class $\mathrm{C}$ hospitals. Class $\mathrm{D}$ hospitals are only able to provide general medicines and dental care. Same as Class $\mathrm{C}$ hospitals, Class D hospitals also accommodate the referral of level 1 health care facilities.

According to Indonesian Health Profile, Indonesian hospital's growth is currently increasing. Since the year of 2005 , the number of hospitals is increasing from 1,268 to 2,488. By November 2016, the number of hospitals was significantly increased into 2,588 , or about $104 \%$ higher than 2005 . The growth of hospitals will benefit people, in terms of their access to health care. While in the other hand, such condition will turn into a liability if the growth is not being balanced by efforts to make hospitals efficient, especially in the era of National Health Insurance provided by BPJS Kesehatan in Indonesia.

Theoretically, the policy to apply health insurance universally, will improve people's access to health care facilities. But in Thailand, this policy has also squeezed out such big amount of resources and needs to be intensively supervised. In the beginning of universal coverage in Thailand, hospitals have only restricted amount of funds and thus, have caused financial problems for hospitals themselves. Dismuke (1999) shown that the use 
of DRG payment in insurance system, will improve the efficiency of hospitals in Portugal.

Malonda in 2015 stated in his research that, in the beginning of the implementation of BPJS Kesehatan in RSUD Dr. Sam Ratulangi Tondano/Dr. Sam Ratulangi Regional Hospital. Nationally, the application of health insurance has brought some negative effects to the performance of financial, productivity and hospital efficiency. Chriswardani on 2015 also found that the first year of BPJS Implementation, the income of RSUD in Semarang was relatively declining, since some of INA CBG tariffs are lower than the original hospital tariffs.

To be able to survive in the era of National Health Insurance, efficient hospital management will have to include quality and cost control, especially BLU/BLUD hospitals, which were specifically formed to be able to manage their operations with the principles of efficiency and effectivity.

The purpose of this research is to measure the efficiency level in BLU/BLUD hospitals in Indonesia with DEA approach to be able to acquire images about Indonesian hospital efficiency level and also the stragies to reach optimum efficiency. The data for this is acquired from 82 BLU hospitals and BLUD in the year of 2017 in the form of online hospital reporting system by Indonesian Ministry of Health.

\section{Methods}

\subsection{The Concept of Efficiency}

The term of efficiency is commonly used in the economics, which usually are referring to the most optimal way in utilizing resources in order to producing goods or services. Efficiency, in the term of Hospital Efficiency, means the most optimal utilization of inputs in the hospitals in order to produce the number of maximum output possible. In the studies conducted by Europe Path project, in order to measure the achievement of efficiency, efficiency itself is divided into sub-dimensions which are: 'the relationships of the treatment's input and output', and 'the utilization of technology in order to produce the best treatment possible'.

In the corporate's perspectives, there are three kinds of efficiency. First, Technical Efficiency which reflects the company's ability to achieve optimum outputs by utilizing certain inputs. Second, Allocative Efficiency, which reflects the company's ability in order to optimize input utilization with certain price structure and technology. Third, Economic Efficiency which is the combination between technical efficiency and allocative efficiency. Economic Efficiency implies the concept of least cost production. To reach certain outputs, companies are classified as economically efficient when they are able to utilize the costs where the price of each output unit is at the most minimal.

In the health care services, Institute of Medicine of the National Academies described that economic efficiency is generally stated as the relationship of the number and quality of certain outputs by utilizing certain inputs which can minimize the production costs. Different combination of capital, labor and raw materials (doctors, nurses, etc.), are able to be utilized as inputs to produce numbers and qualities of some certain outputs. Generally, there is only one combination of input with the lowest production costs which can produce some certain outputs.

The issues about efficiency were brought up to answer questions about whether the service costs incurred by certain units are sufficient. Hospitals with low service volumes are most likely to have very high unit costs or are operating with rather old equipment like $\mathrm{x}$-rays and radiology equipment. These equipment might require the operator to operate them multiple times in order to achieve the best results possible. In that case, although patients or third parties would not mind to pay certain service costs, these people would not pay the services efficiently ${ }^{11}$

\subsection{The Methods of Efficiency Measurements}

Yazar A. Oscan (2014), efficiency measurements are done by various methods, parametrically and non-parametrically. Some methods used in measuring the efficiency are analysis ratio, least-squares regression (LSR), total factor productivity (TFP), stochastic frontier analysis (SFA) and data envelopment analysis (DEA). ${ }^{12}$

Research done by Hussey, et al. (2009) found that the majority methods used to measure efficiency in the health care fields in all around the world is the frontier analysis methods with DEA included ${ }^{(13)}$. One of the advantages of DEA is its ability to accommodate many inputs and outputs in many dimensions. Efficiency measurements are more accurate because in hospitals, the inputs and the outputs are pretty various and are connected to each other.

Ozcan ${ }^{(12)}$ stated in his book about the measurement of efficiency by using DEA methods have now been developing and are commonly used in measuring technical efficiency in hospitals and other health care institutions in the U.S and all around the world like in Spain (Pina \& Torres, 1996; Sola \& Prior, 2001; Dalmau-Atarrodana \& Puig-Junoy, 1998), Taiwan (Chang, 1998), Thailand (Valdmanis et al., 2004), Turkey (Ersoy et al., 1997; Sahin \& Ozscan, 2000), Greece (Giokas, 2001; Athanassopoulus \& Gounaris, 2001), 
Germany (Helmig \& Lapsay, 2001), Canada (Oullette \& Vierstraete, 2004), Britain (Field \& Emrouznejad, 2003; McCaliion et al., 2000), Belgium (Creteur et al., 2003) and Sweden (Gerdtham et al., 1999). Comparison study between countries have also been done by Mobley and Magnussen in 1998 and also Steinman and Zweifel in 2003.

Ramanathan (2003) stated that DEA is a linear program-based technique in measuring the efficiency of organization units named Decision Making Units (DMUs). DMUs are organizations or entities, whose efficiency will be measured relatively to other homogeneous entities. Homogeneous means the inputs and outputs from the DMUs evaluated must be the same or similar. DMUs can mean commercial entities or public, just like commercial banks or government, private and public school, hospitals etc. ${ }^{(14)}$

The Data Envelopment Analysis compares the efficiency level of one decision making units (DMUs) by using variative input and output with typical DMUs. The calculation of efficiency by using DEA results the score of 0 to 1 (most efficient). DMU with the score of less than 1 is classified as inefficient. Mathematical models of DEA can be described as below:

$$
\begin{aligned}
& \max E_{m}=\frac{\sum_{J=0}^{j} v_{j m} y_{j m}}{\sum_{i=0}^{i} u_{i m} x_{i m}} \\
& \text { Subject to } \\
& 0 \leq \frac{\sum_{J=0}^{j} v_{j m} y_{j m}}{\sum_{i=0}^{i} u_{i m} x_{i m}} \leq 1 ; n=1,2, K, N \\
& v_{j m} u_{j m} \geq 0 ; i=1,2, K, I ; j=1,2, K, J
\end{aligned}
$$

Where:

Em is the efficiency of DMU to $m$

Yjm is an output to $\mathrm{j}$ from DMU to $\mathrm{m}$

Vjm is the weight of the above output

Xim is the input to I from DMU to $\mathrm{m}$

Uim is the weight of the above input

Yjn and xin is the output to $\mathrm{j}$ and the input to I respectively and from DMU to $n, n=1,2, \mathrm{~N}$

There are a few DEA models which might be used depending on the conditions of the problem. The form of DEA can be identified based on economy scale and the orientation of the model. There are four models of DEA which can be used in the research, they are CRS Input, CRS Output, VRS Input, dan VRS Output. CRS and VRS are showing the assumptions used, while input and output are showing the orientation of the research.

DEA was found by Farrell on 1957 and was developed by Charnes, Cooper and Rhodes on 1978 which was known as the model of CCR. In its growth DEA has been modified by Banker, Charnes and Cooper on 1984, and that it was named BCC. Unlike CCR which uses the assumption of Constant Return to Scale (CRS), the BCC model uses the assumption of Variable Return to Scale (VRS).

CRS assumption requires DMU to be able to increase or decrease the input and the output linearly without the need to experience of the rise or the drop of the efficiency score. While VRS assumption does not require the change of Input and Output of particular DMU to occur linearly, so that the increasing returns to scale (IRS) and the decreasing returns to scale (DRS) are allowed. CRS assumptions are suitable to utilize when all of the DMUs are working on their most economical scale. But the truth is, there are conditions that might cause some productions to not working optimally. Therefore, the BCC model is the better choice to utilize in such condition.

Input orientation may be used when there is some certain reduction of input to increase efficiency. Input orientation assumes that management has a better control toward Input rather than Output, or in other words, management is able to raise or to reduce the input easily. For example, in the field of health, the reduction or the increase of the number of doctors in certain hospitals. Unlike the input orientation, output orientation is used when the increase of the output with the available input to increase the efficiency score. This means that management has more control toward output rather than input. This research utilizes DEA models with VRS and output orientation because the subjects for this research are government-owned hospital which are easier in controlling their output rather than input which are bonded to the regulations of the government.

\subsection{The Source of the Data and the Variables of the Research}

The availability of the data for the hospital's resources and performance are still very restricted. This research utilizes secondary data on the online based hospital's reporting system provided by the Indonesian Ministry of 
Health in the period of 2017 which were the only source available in national scale. The input and output indicators in this research is based on the availability of the data nationally available in the database. The samples of the hospitals used were sourced from the list of the BLU and BLUD hospitals on the funding of health facility research by Indonesian Ministry of Health in the year of 2016.

In the beginning, the samples were only 84 hospitals, but soon after data cleaning was performed based on the availability of the data, the indicators used in the online hospital reporting database was reduced by 2 hospitals, resulting in only 82 hospitals were used as the samples.

In the determination of input indicators, this research focused on two things, earlier studies about the utilization of input indicators in the hospitals with the DEA approach and also the availability of the said indicators in the hospital's reporting database. Earlier research shown that the number of doctors, nurses, other staffs and beds in hospitals are the most utilized input indicators. Based on those previous research, this research will use the number of doctors, nurses, other staffs and beds as the input indicators.

Studies with DEA approach divided indicators into three which can be used as output indicators, which are outpatients, inpatients and emergency patients. Based on previous studies and the availability of data inside the Indonesian hospital reporting systems, the output indicators used in this research are outpatients, inpatients and emergency patients.

\section{Results and Analysis}

Out of 82 hospital samples, there were 9 class A hospitals, 37 class B hospitals and 36 class C hospitals. Hospitals in Indonesia are divided into 5 regions based on the payment systems of national health security with INA-CBGs tariff. Regionalization in INA-CBGs tariffs was meant to accommodate distribution costs of medicines and medical equipment in Indonesia. Regionalization is determined by Consumer Pricing Index (IHK) from Statistics Indonesia. The spread of the research samples, based on the regionalization are 36 hospitals on regional 1, 15 hospitals in regional 2, 19 hospitals in regional 3,5 hospitals in regional 4 and 7 hospitals in regional 5.

The descriptive results for the average of input numbers in the samples of the research are 341 beds, 82 doctors, 344 nurses and 387 other staffs. The average output for outpatients are 116.711, for inpatients are 22.363 and emergency patients are 19.348 annually. The result of descriptive statistics of input and output of the hospitals are including the minimums, maximums, means and deviation standards shown on table 2 below:

Table 2. Descriptive statistics of inputs and outputs

\begin{tabular}{ccccc}
\hline Input/Output & Minimum & Maximum & Mean & Deviation Standard \\
\hline Beds & 96 & 1.038 & 341 & 234 \\
Doctors & 15 & 461 & 82 & 88 \\
Nurses & 20 & 1.404 & 344 & 274 \\
Other Staffs & 38 & 2.016 & 387 & 342 \\
Outpatients & 7.000 & 576.863 & 116.711 & 101.348 \\
Inpatients & 2.000 & 144.533 & 22.363 & 22.206 \\
Emergency Patients & 2.420 & 46.350 & 19.348 & 10.675 \\
\hline
\end{tabular}

Hospitals are considered efficient if all the resources they possess were spent optimally and no other rooms to increase the outputs without changing the inputs used. Technical efficiency scores for hospitals will be 1 or 100 percent. In the other hand, hospitals are considered as inefficient if there are still rooms to reduce the utilization of their inputs without affecting current outputs. Technical efficiency score for these hospitals are less than 1. Based on the above statements, in DEA analysis are between 0 until 1.

\subsection{Efficiency Scores}

The technical efficiency score for BLU hospitals were calculated by using the 'output-oriented' and Variable Returns to Scale (VRS). Technical efficiency scores were provided in Table 3. From 82 hospitals, 28 hospitals or $34 \%$ were technically efficient. The average number of hospital technical efficiency is 78.9 or 0,789 , which means that Indonesian hospital Technical Efficiency scores are needed to be increased by $21.1 \%$.

In the DEA analysis model, the term of efficient is not necessarily absolute, but rather relative to other inefficient hospitals. In judging certain efficiency units, the estimation process was conducted by comparing the said unit's performance with other efficient units. The more efficient units were used as the reference in order to assess the other hospital's efficiency. The performance of efficient references in variative assessments dimensions shown 
why inefficient units are considered inefficient.

Table 3. Technical efficiency scores for the BLU/BLUD hospitals in Indonesia.

\begin{tabular}{|c|c|c|c|c|c|c|c|}
\hline Hospital & Score & Hospital & Score & Hospital & Score & Hospital & Score \\
\hline $\begin{array}{l}\text { RS Dr. R. } \\
\text { Soetijono } \\
\text { Blora }\end{array}$ & 1 & $\begin{array}{l}\text { RSUD Dr Doris } \\
\text { Sylvanus }\end{array}$ & 0.773236 & $\begin{array}{l}\text { RSUD Kab. } \\
\text { Jombang }\end{array}$ & 0.925421 & $\begin{array}{l}\text { RSUD Provinsi } \\
\text { Kepulauan Riau } \\
\text { Tanjungpinang }\end{array}$ & 0.49787 \\
\hline $\begin{array}{c}\text { RSU Andi } \\
\text { Makkasau } \\
\text { Pare2 }\end{array}$ & 0.416519 & $\begin{array}{l}\text { RSUD Dr H Abdul } \\
\text { Moeloek }\end{array}$ & 1 & $\begin{array}{c}\text { RSUD } \\
\text { Karangasem }\end{array}$ & 1 & $\begin{array}{l}\text { RSUD R Syamsudin } \\
\text { SH Sukabumi }\end{array}$ & 1 \\
\hline RSU Bangli & 1 & RSUD Dr H Soemarno S & 1 & $\begin{array}{l}\text { RSUD } \\
\text { Kardinah }\end{array}$ & 1 & $\begin{array}{l}\text { RSUD Sanjiwani } \\
\text { Gianyar }\end{array}$ & 0.720587 \\
\hline RSU Cibabat & 0.510967 & $\begin{array}{l}\text { RSUD Dr Soegiri } \\
\text { Lamongan }\end{array}$ & 0.927707 & $\begin{array}{c}\text { RSUD } \\
\text { Kepahiang }\end{array}$ & 1 & RSUD Sawah Lunto & 0.775345 \\
\hline RSU Cilacap & 0.497531 & RSUD Dr. Abdul Rivai & 0.392392 & $\begin{array}{c}\text { RSUD } \\
\text { Kertosono }\end{array}$ & 1 & $\begin{array}{l}\text { RSUD Taman Husada } \\
\text { Bontang }\end{array}$ & 0.662752 \\
\hline RSU Kolaka & 0.622165 & $\begin{array}{l}\text { RSUD Dr. Achmad } \\
\text { Mochtar }\end{array}$ & 0.855608 & $\begin{array}{l}\text { RSUD Kota } \\
\text { Mataram }\end{array}$ & 1 & RSUD Tangerang & 0.259493 \\
\hline RSU Praya & 0.825147 & $\begin{array}{l}\text { RSUD Dr. Fauziah } \\
\text { Bireun }\end{array}$ & 1 & $\begin{array}{l}\text { RSUD Kota } \\
\text { Surakarta }\end{array}$ & 1 & $\begin{array}{l}\text { RSUD Ulin } \\
\text { Banjarmasin }\end{array}$ & 0.589823 \\
\hline $\begin{array}{l}\text { RSU Prof Dr } \\
\text { WZ Johanes }\end{array}$ & 0.519969 & $\begin{array}{l}\text { RSUD Dr. H. Kumpulan } \\
\text { Pane }\end{array}$ & 0.40257 & $\begin{array}{l}\text { RSUD Kota } \\
\text { Yogyakarta }\end{array}$ & 1 & $\begin{array}{c}\text { RSUD } \\
\text { Wates Kulonprogo }\end{array}$ & 1 \\
\hline RSU Sambas & 1 & $\begin{array}{l}\text { RSUD Dr. H. Moch. } \\
\text { Ansari Saleh }\end{array}$ & 0.697755 & $\begin{array}{l}\text { RSUD La } \\
\text { Temmamala } \\
\text { Soppeng }\end{array}$ & 0.974381 & RSUD Wonosari & 1 \\
\hline $\begin{array}{c}\text { RSU } \\
\text { Sawerigading }\end{array}$ & 0.502776 & $\begin{array}{l}\text { RSUD dr. H. Moh. } \\
\text { Anwar Kabupaten } \\
\text { Sumenep }\end{array}$ & 0.517206 & RSUD Lahat & 0.719148 & $\begin{array}{l}\text { RSUP Dr. Hasan } \\
\text { Sadikin }\end{array}$ & 1 \\
\hline $\begin{array}{c}\text { RSU } \\
\text { Tenriawaru } \\
\text { Bone }\end{array}$ & 0.607062 & $\begin{array}{l}\text { RSUD Dr. H. Yulidin } \\
\text { Away }\end{array}$ & 0.651397 & $\begin{array}{c}\text { RSUD M. Th. } \\
\text { Djaman } \\
\text { Sanggau }\end{array}$ & 0.610677 & $\begin{array}{c}\text { RSUP Dr. } \\
\text { Mohammad Hoesin }\end{array}$ & 0.703778 \\
\hline $\begin{array}{l}\text { RSU Undata } \\
\text { Palu }\end{array}$ & 0.862505 & $\begin{array}{c}\text { RSUD Dr. Ibnu Sutowo } \\
\text { Baturaja }\end{array}$ & 0.527159 & $\begin{array}{l}\text { RSUD } \\
\text { Majalaya }\end{array}$ & 1 & $\begin{array}{l}\text { RSUP Dr. Soeradji } \\
\text { Tirtonegoro Klaten }\end{array}$ & 0.690921 \\
\hline $\begin{array}{c}\text { RSUD Abdul } \\
\text { Wahab } \\
\text { Sjahranie }\end{array}$ & 0.421564 & $\begin{array}{l}\text { RSUD dr. Loekmono } \\
\text { Hadi Kudus }\end{array}$ & 0.836246 & $\begin{array}{l}\text { RSUD } \\
\text { Majenang }\end{array}$ & 0.769018 & RSUP Fatmawati & 0.963215 \\
\hline $\begin{array}{l}\text { RSUD Aji } \\
\text { Batara Agung } \\
\text { Dewa Sakti }\end{array}$ & 1 & $\begin{array}{l}\text { RSUD Dr. Moh Saleh } \\
\text { Probolinggo }\end{array}$ & 0.701063 & RSUD Meuraxa & 0.758783 & RSUP H. Adam Malik & 0.609472 \\
\hline $\begin{array}{c}\text { RSUD } \\
\text { Arosuka,Solok }\end{array}$ & 0.315854 & $\begin{array}{l}\text { RSUD dr. R. GOETENG } \\
\text { TAROENADIBRATA }\end{array}$ & 1 & $\begin{array}{l}\text { RSUD Muara } \\
\text { Enim }\end{array}$ & 0.753488 & $\begin{array}{l}\text { RSUP Prof. Dr. R. D. } \\
\text { Kandou }\end{array}$ & 1 \\
\hline RSUD Bangil & 0.869401 & $\begin{array}{l}\text { RSUD Dr. R.Soedjati } \\
\text { Soemodiardjo }\end{array}$ & 0.829605 & $\begin{array}{l}\text { RSUD Nagan } \\
\text { Raya }\end{array}$ & 1 & $\begin{array}{l}\text { RSUP Sanglah } \\
\text { Denpasar }\end{array}$ & 1 \\
\hline $\begin{array}{c}\text { RSUD } \\
\text { Banyuasin }\end{array}$ & 0.701231 & RSUD Dr. Saiful Anwar & 0.794836 & $\begin{array}{l}\text { RSUD Pandan } \\
\text { Arang Boyolali }\end{array}$ & 0.675473 & Mean & 0.78901387 \\
\hline $\begin{array}{l}\text { RSUD Bayu } \\
\text { Asih }\end{array}$ & 0.830738 & $\begin{array}{l}\text { RSUD Dr. Soedomo } \\
\text { Trenggalek }\end{array}$ & 0.63801 & $\begin{array}{l}\text { RSUD Pantura } \\
\text { M.A.Sentot } \\
\text { Patrol }\end{array}$ & 1 & SD & 0.206976212 \\
\hline RSUD Bekasi & 1 & $\begin{array}{l}\text { RSUD dr. Soekardjo } \\
\text { Tasikmalaya }\end{array}$ & 0.742276 & $\begin{array}{c}\text { RSUD } \\
\text { Pelabuhan Ratu }\end{array}$ & 0.767716 & Min & 0.259493 \\
\hline RSUD Ciamis & 1 & $\begin{array}{l}\text { RSUD H. Boejasin } \\
\text { Pelaihari }\end{array}$ & 1 & $\begin{array}{l}\text { RSUD Prof Dr } \\
\text { M.A Hanafiah }\end{array}$ & 0.779253 & Max & 1 \\
\hline $\begin{array}{l}\text { RSUD Datu } \\
\text { Beru } \\
\text { Takengon }\end{array}$ & 1 & $\begin{array}{l}\text { RSUD K.M.R.T Wongso } \\
\text { Negoro Semarang }\end{array}$ & 0.895361 & $\begin{array}{l}\text { RSUD Prof Dr. } \\
\text { M Soekarjo } \\
\text { Banyumas }\end{array}$ & 0.972779 & Efisien & 28 \\
\hline $\begin{array}{l}\text { RSUD Depati } \\
\text { Hamzah }\end{array}$ & 0.496313 & RSUD Kab. Batang & 0.764663 & $\begin{array}{l}\text { RSUD Prof. Dr. } \\
\text { H. Chatib } \\
\text { Quzwain }\end{array}$ & 0.572912 & Tidak Efisien & 54 \\
\hline
\end{tabular}

According to efficiency scores on the above table, inefficient hospitals are grouped into low, medium, and highly inefficient. There are 22 inefficient hospitals which reached the score between $75 \%-99.9 \%$ and can be classified as low level inefficient units. There are 23 hospitals with efficiency scores of 50\%- 74.9\% which are classified as medium level inefficient. Nine hospitals that are grouped as highly inefficient are the ones with efficiency level of less than $50 \%$. 
Class-wise, the most efficient hospitals are hospital class $\mathrm{C}$ with $38.9 \%$. This is caused by less input complexities managed by class $\mathrm{C}$ hospitals were not as complicated as class A and B hospitals. Class C hospitals in Indonesia have successfully managed their resources in producing optimum output. Earlier studies shown that hospitals' classes were affecting their efficiency level ${ }^{(15,24-26)}$.

Table 4. Indonesian hospital efficiency level based on their classes

\begin{tabular}{cccc}
\hline Hospital Classes & Efficient & Inefficient & Total \\
\hline Class A & 3 & 6 & 9 \\
& $33.3 \%$ & $66.7 \%$ & $100.0 \%$ \\
Class B & 11 & 26 & 37 \\
& $29.7 \%$ & $70.3 \%$ & $100.0 \%$ \\
Class C & 14 & $61.1 \%$ & 36 \\
& $38.9 \%$ & & $100.0 \%$ \\
\hline
\end{tabular}

The findings in this research are expected to be Hospital's Policy Makers concern that in an effort to raise hospital's classes like resources and beds replenishment, must be followed with services improvements. Hu and Huang ${ }^{(27)}$ stated that the increase of hospital's beds may increase efficiency, but it has to be followed with the balance between capacity and the utilization of the said hospital's services.

With their current available inputs, class $\mathrm{C}$ hospitals in Indonesia are considered as more efficient units because they are able to provide more optimum outputs compared to their class A and B counterparts. This output optimization levels may also be affected by hospital tiered referral system in health care facilities in Indonesia. Generally, Indonesian health care facility systems are divided into two which are primary health care facility e.g. Puskesmas (Pusat Kesehatan Masyarakat), clinics, and more advanced, referral health care facilities e.g. class A, $\mathrm{B}, \mathrm{C}$ and D hospitals. In this era of national health insurance program, Indonesian government applies the rules about referral health care facilities where patients are no longer allowed to enter class A and B hospitals directly without any referrals from class $\mathrm{C}$ hospital. When class $\mathrm{C}$ hospitals are unable to proceed with their available resources, they will make reference letters for patients to go to class A or B hospitals to be treated with further actions.

Compared to class A and B hospitals, class $\mathrm{C}$ hospitals are more efficient, but the number of inefficient hospitals is still high, which are 22 hospitals or $61.1 \%$. This high level of inefficient hospitals is caused by the excessive amount of resources owned compared to the number of output produced. The number of output in this case is the number of patients. The low number of patients in today's hospitals are caused by the ongoing referral system which require patients to come to primary health care facilities such as Puskesmas and clinics before other more advanced, referral health care facilities. The hospitals' referral systems require patients to go to the primary health care facilities such as Puskesmas. Patients are no longer allowed to visit advanced health care facilities such as hospitals, if their current symptoms are treatable by primary health care facilities. This causes the decline in number of patients that came to the hospitals.

This research also showed that, Puskesmas as a gate keeper for tiered referral system has been working appropriately, although it also has brought some negative impacts to hospitals such as the decrease of efficiency. Hospitals that have previously possessed big amount of resources are now being less efficient due to the decrease of their patients visit. In order to overcome such condition, the best strategy is to perform input retribution by transferring doctors, nurses, and other staffs to Puskesmas in order to achieve efficiency while strengthening the basic health care system in Indonesia.

Hospitals of which resources were plenty in producing big outputs, which in this context means patients, are now less optimum due to the decrease of patients visit. To overcome such condition, one of the strategies that can be applied are executing retributions such as doctors, nurses and other staffs from hospitals to Puskesmas to achieve efficiency and strengthen Indonesia's basic health care system.

Table 5. Efficiency Level Based on Hospital's Location in Indonesia.

\begin{tabular}{cccc}
\hline Location & Efficient & Inefficient & Total \\
\hline Regional 1 & 14 & 22 & 36 \\
& $38.9 \%$ & $61.1 \%$ & $100.0 \%$ \\
Regional 2 & 4 & 11 & 15 \\
& $26.7 \%$ & $73.3 \%$ & $100.0 \%$ \\
\hline
\end{tabular}




$\begin{array}{cccc}\text { Regional 3 } & 6 & 13 & 19 \\ & 31.6 \% & 68.4 \% & 100.0 \% \\ \text { Regional 4 } & 2 & 3 & 5 \\ & 40.0 \% & 60.0 \% & 100.0 \% \\ \text { Regional 5 } & 2 & 5 & 7 \\ & 28,6 \% & 71,4 \% & 100 \%\end{array}$

On the above table, it is shown that Regional 4 have the most number of efficient hospitals with the number of efficient hospitals of $40 \%$, While regional 2 have the most inefficient hospitals which are $73.3 \%$. Descriptively, the result of this study did not show significant hospital efficiency score. The majority on each regional, inefficient hospitals are bigger than the efficient counterparts. The result shown that descriptively, regionalization affects only insignificant impact to hospital's efficiency. This is similar to previous result on class efficiency analysis where inefficient hospitals are caused by Jaminan Kesehatan Nasional (JKN), especially the application of tiered referral system. Studies conducted in Thailand and Indonesia shown that any regulations regarding national health insurance have brought negative impacts toward financial, productivity and efficiency especially on the beginning on their application ${ }^{6,8}$. Such phenomena are usually occurred on their early stages of regulation's application. As time goes by, Dismuke (1999) stated that in Portugal, hospital's efficiency will improve. Nevertheless, the improvement of hospital's efficiency shall also be followed by the improved management of health insurance system, referred health care system and regulations for more rational man-power and payment distribution.

\subsection{The Frequency of Referred Health Care System}

In order to distinguish efficient hospitals, some research suggested to find out the frequency of each efficient hospital to act as referred facilities. Out of 28 technically efficient hospitals, Karangasem hospital, which is classified as class $\mathrm{C}$ hospital, is the most referred hospitals with the frequency of 33 times and matched the table 4 where the most efficient hospitals are class C hospitals. On class B hospitals, RSUD Bekasi is the most referred hospital with the frequency of 26 times. On class A hospitals, RSUP Dr. Hasan Sadikin is the most referred hospital with the frequency of 10 times. The above results can be used as benchmarks for other inefficient hospitals to strategically create the utilization of their resources in order to produce the most optimum output.

\subsection{Strategies to Improve Efficiency}

In the era of national health insurance, Indonesian hospitals are demanded to be able to operate efficiently. Generally, in order to improve hospital's technical efficiency is by reducing the input or increasing the output. The average of input or output that were unable to be improved by 54 inefficient hospitals are shown in table 5 . The average number of available beds of all inefficient hospitals are 354 beds and are required to be reduced into 296 beds. The average number of available doctors are 83 doctors and were needed to be reduced into 71 doctors. The average number of nurses and tocologists are 370 and need to be reduced by 278 in order to achieve efficiency. Next up, the average of other staffs in inefficient hospitals are 401 and need to be reduced into 344 .

Table 6. The average of Original Score and Input - Output Projection of inefficient hospitals

\begin{tabular}{cccc}
\hline \multirow{2}{*}{ Input/Output } & \multicolumn{2}{c}{ Average Score } & \multirow{2}{*}{ Difference Percentage } \\
\cline { 2 - 3 } & Original & Projection & $-16.4 \%$ \\
Beds & 354 & 296 & $-14.5 \%$ \\
Doctors & 83 & 71 & $-24.9 \%$ \\
Nurses \& Tocologists & 370 & 278 & $-14.2 \%$ \\
Other Staffs & 401 & 344 & $46.0 \%$ \\
Outpatients & 105.362 & 153.842 & $67.5 \%$ \\
Inpatients & 17.766 & 29.761 & $53.8 \%$ \\
Emergency Patients & 17.644 & 27.139 & $5 \%$ \\
\hline
\end{tabular}

In government-owned hospitals, the decrease of the above input is rather hard to execute, especially regarding man-power. Strategies that can be done are executing man-power relocation from hospitals with excessive human resources, into the ones with human resources deficiency. This strategy is possible to execute, while decision makers are advised to be more careful while keep on paying attention on the needs of public for health care in the area of the managed hospitals and the rules of minimum standard for human resources in hospitals. In 
DEA analysis, input target for identified hospitals are relative to other hospital's performance which are also affected by other factors such as population needs, and the weight of the diseases.

The other strategies that can be used by hospital management is to improve efficiency by maximizing the productivity of each input. With the increase of productivity, hospitals may reach optimum output. In this study, outputs are referring into the number of patients, whether inpatients, outpatients and emergency patients. In order to minimize the idle capacity on inpatients sectors, the output target in the hospitals will have to be increased by $67.5 \%$ or 17.766 into 29.761 patients annually. Emergency patients are expected to be increased by $53.8 \%$ or from about 105.362 into 153.842 annually. For emergency patients, the improvement is expected to reach $46 \%$ or from about 17.644 into 27.139 annually.

\section{Conclusions}

In this research paper, the scoring of hospitals in Indonesia were conducted by using DEA Analysis which can generate the technical efficiency score in Indonesian hospitals based on classes, locations, target determination (the level of input and output so that hospitals are relatively efficient). By using DEA analysis, results shown that 54 or about $65.9 \%$ inefficient hospitals in Indonesia are inefficient compared to other hospitals. The average score for hospital efficiency is $78.9 \%$, which proves the need for hospital performance increase especially output numbers which are generally $21.1 \%$.

The results of this research have provided a few inputs for hospitals' decision makers in Indonesia. While keep on paying attention on health care needs for society in the proximity of hospitals, the estimation for inefficiency in this research may help in formulating regulations in the increase of hospital efficiency by maximizing input productivity or relocating excessive hospitals' resources such as medical and non-medical human resources, to Puskesmas. This can be done so that hospitals may have more efficient outputs and are able to strengthen their primary health care facilities like Puskesmas as the edge of the spear for Indonesian health quality building. It is also advised for hospitals in Indonesia to maximize their resources to be able to increase the patients visit or hospital utilization to a more optimum level.

\section{Acknowledgements}

One of several limitations of this research are the data used to measure hospitals' efficiency only valid for a year. Longitudinal studies will be more useful in monitoring the development of hospital efficiency in Indonesia but are rather hard to be executed due to the limitations of the available of data resources. There are also other factors that can affect hospital's efficiency that have not been studied yet, therefore next researchers are advised to explore those factors and analyze them.

\section{References}

Caballer-Tarazona, M., Moya-Clemente, I., Vivas-Consuelo, D., \& Barrachina-Martínez, I. (2010). A model to measure the efficiency of hospital performance. Mathematical and Computer Modeling, 52, 1095-1102. https://doi.org/10.1016/j.mcm.2010.03.006

Cellini, R., Pignatoro, G., \& Rizzo, I. (1999). Competition and efficiency in health care an analysis of the Italian case.pdf. JEL Classification, 1, 11. https://doi.org/10.1023/A:1008737506560

Chang, H., Cheng, M.-A., \& Das, S. (2004). Hospital ownership and operating efficiency: Evidence from Taiwan. European J. of Operational Res., 159, 513-527. https://doi.org/10.1016/S0377-2217(03)00412-0

Chriswardani, S., Sutopo, P., Putri Asmita, W., Pawit, S., \& Puri Nur, M. (2015). The Implementation of National Health Security Problems in Hospitals of Semarang City, 2014. Faculty of Public Health, Public Health Sciences, Universitas Diponegoro. Presented in INA-HEA 2016.

Dismuke, C. E., \& Sena, V. (1999). Has DRG payment influenced the technical efficiency and productivity of diagnostic technologies in Portuguese public hospitals? An empirical analysis using parametric and non-parametric. https://doi.org/10.1023/A:1019027509833

Ersoy, K., Kavuncubasi, S., Ozcan, Y. A., \& Harris, J. M. (1997). Technical efficiency of Turkish hospital: DEA approach. J. Med. Syst., 21, 67-74. https://doi.org/10.1023/A:1022801222540

Groff, J., Lien, D., \& Su, J. (2007). Measuring efficiency gains fromhospital mergers. Res Health Finance Management, 11(1), 77-90.

Hofmarcher, M. M., Paterson, I., \& Riedel, M. (2002). Measuring hospital efficiency in Austria: A DEA approach. Health Care Manag. Sci., 5, 7-14. https://doi.org/10.1023/A:1013292801100

Hu, J.-L., \& Huang, Y.-F. (2004) Technical efficiencies in large hospitals: A managerial perspective. Int J Manag., 
21(4), 506-51.

Hussey, P. S., De Vries, H., Romley, J., Wang, M. C., Chen, S. S., Shekelle, P. G., \& McGlynn, E. A. (2009). A systematic review of health care efficiency measures: Health care efficiency. Health Services Research, 44(3), 784-805. https://doi.org/10.1111/j.1475-6773.2008.00942.x

Jacobs, R., Smith, P. C., \& Street, A. (2006). Measuring Efficiency in Health Care: Analytic Techniques and Health Policy. Cambridge: Cambridge University Press. https://doi.org/10.1111/j.1468-0335.2009.00763.x

Karagiannis, R. (2013). A system-of-equations two-stage DEA approach for explaining capacity utilization and technical efficiency. Annals of Operations Research, 1-19. https://doi.org/10.1007/s10479-013-1367-7

Ministry of Home Affairs. (2016). Local General Services. Direcotrate General of Area Local Financial Development, Indonesian Republic Ministry of Home Affairs. Retrieved from http://keuda.kemendagri.go.id/datin/index/3/2014

Ministry of Finance. (2016). A Decade for BLU Toward Better Public Services. Government Communication and Information Services Bureau, Indonesian Republic Ministry of Communication and Information. Retrieved from https://kominfo.go.id/index.php/content/detail/8409/satu-dekade-blu-menuju-pelayanan-publik-yanglebih-baik/0/artikel_gpr

Malonda, T. D., Rattu, A. J. M., \& Soleman, T. (2015). The Claim Filing Analysis of Health Badan Penyelenggara Jaminan Sosial (BPJS) Kesehatan in Dr. Sam Ratulangi Tondano Local Hospital. Research Article, Magisterial Program, Univesitas Sam Ratulangi. Manado.

McKillop, D. G., Glass, J. C., Kerr, C. A., \& McCallion, G. (1999). Efficiency in Northern Ireland hospitals: A non-parametric analysis. Econ. Soc. Rev., 30, 175-196.

Ngorsuraches, S., \& Sornlertlumvanich, A. (2006). Determinants of hospital loss in Thailand: Experience from the first year of a universal coverage health insurance program. Health Care Management Science, 9(1), 59-70. https://doi.org/10.1007/s10729-006-6280-z

Nicola, A. De, Gitto, S., Mancuso, P., \& Tor, R. (2012). A two-stage DEA model to evaluate the efficiency of the Italian health system. Munich Personal RePEc Archive, (39126).

Ozcan, Y. A. (2014). Health Care Benchmarking and Performance Evaluation; An assessment Using Data Envelopment Analysis (DEA) (2nd ed.). Springer. New York. ISBN 978-0-387-75448-2

Ozcan, Y. A., Luke, R. D., \& Haksever, C. (1992). Ownership and organizational performance: A comparison of technical efficiency across hospital types. Med. Care, 30,780-794,

Rahman, M. (2006). Measuring and explaining the managerial efficiency of private medical clinics in Bangladesh: an exploratory study. Thesis. Brandeis University

Ramanathan, R. (2003). An Introduction to Data Envelopment Analysis: A Tool for Performance Measurement. Sage Publications New Delhi.

Tiemann, O., \& Schreyögg, J. (2009). Effects of ownership on hospital efficiency in Germany. BuR Bus Res., 2(2), 115-145. https://doi.org/10.1007/BF03342707

Varabyova, Y., \& Schreyogg, J. (2013). International comparisons of the technical efficiency of the hospital sector: Panel data analysis of OECD countries using parametric and non-parametric approaches. Health Policy, 112(1-2), 70-79. https://doi.org/10.1016/j.healthpol.2013.03.003

Veillard, J., Champagne, F., Klazinga, N., Kazandjian, V., Arah, O. A., \& Guisset, A. (2005). A performance assessment framework for hospitals: the WHO regional office for Europe PATH project. International Journal for Quality in Health Care, 17(6), 487-496. https://doi.org/10.1093/intqhe/mzi072

Zelman, W. N., McCue, M. J., Millikan, A. R., \& Glick, N. D. (2003). Financial Management of Health Care Organizations: An Introduction to Fundamental Tools, Concepts, and Applications (2nd ed.). Blackwell Publishing, USA. ISBN: 978-1-118-46656-8

\section{Copyrights}

Copyright for this article is retained by the author(s), with first publication rights granted to the journal.

This is an open-access article distributed under the terms and conditions of the Creative Commons Attribution license (http://creativecommons.org/licenses/by/4.0/). 